\title{
The Impact of Acquisition on Firms Financial Performance (A Case Study of Total Petroleum Ghana LTD)
}

\author{
Kwabena Opoku $^{1 *}$ Prince Kwame Owusu ${ }^{2}$ Pastor Juan Ndjuma Nguema ${ }^{3}$ \\ 1.School of Economies, Ocean University of China, 238 Songling Road, Qingdao 266100, China \\ 2. School of IT Business, Ghana Technology University College, P.M.B 100, Accra-North, Ghana \\ 3. School of It Business, Ghana Technology University College, P.M.B 100, Accra-North, Ghana
}

\begin{abstract}
:
This work evaluates the impact of Acquisition on Firms' Financial Performance. That is a case study of Total Petroleum Ghana. Acquisition is a corporate strategy by which companies take over other company without necessarily buying the other company. The main reasons behind this study were to assess Pre and Post-Acquisition liquidity of total petroleum Ghana, and also to determine the Pre and post-Acquisition profitability of total petroleum Ghana. Moreover to evaluate Pre and Post-Acquisition asset utilization of total petroleum Ghana Company Limited. The results of the findings show that in terms of liquidity, there was a significant impact of the acquisition on the performance. Post-acquisition liquidity ratios indicated significantly higher performance. Moreover, for the profitability and assets utilization, the pre-acquisition performances were better than the four years of the post-acquisition period, though these differences were statistically insignificant. By making references to the findings it can be concluded that the acquisition of Mobil oil by Total petroleum has not been profitable to the company within the first four years. This work recommends that management of the company need to pay more attention on the external environment.
\end{abstract}

Keywords: Acquisition, Petroleum, Profitability, Performance, Firms

DOI: $10.7176 / \mathrm{EJBM} / 12-30-08$

Publication date:October $31^{\text {st }} 2020$

\subsection{Background to the study}

Acquisition is a very important phenomenon in business, as evidence shows an increase in volume of M\&A activities in the past and recent years (Anderson et al, 2001). Acquisition is a combination of two companies where one firm is completely taken over by another firm (Ginsburg et al, 1989).

Acquisition has received a very huge attention in Africa in recent years because it has led to a great impact to a lot of investors. Most of the Businesses in Africa are small and cannot survive the economic pressure and therefore merge in other to be able to globalize. However, it looks obvious that businesses tend to make different decisions relating to acquisition investment during a period of crisis. Hence, there have been a lot of merger and acquisition activities in Ghana in this current time. An examples of merger activities that have occurred in Ghana are the mergers of La Palm Royal Beach Hotel, Berjaya Elmina Beach Hotel and Busua Beach Resort to form Golden Beach Hotels also the merger of Mobil Oil and Total oil to form Total Ghana Limited furthermore the merger of Kumasi Brewery Limited and Ghana Brewery Limited and adopted the name Ghana Breweries Limited.

The merger of Ashanti Gold Fields Company Limited and AngloGold South Africa Limited to form AngloGold Ashanti Limited.

\subsection{Problem Statement}

There have been a lot of evidence on Acquisition activities in recent years among businesses. However, they happen to give at best, a mixed performance to the broad range of stakeholders involved in that actives. A lot of work on acquisition have failed to answer as to whether acquisitions improve the financial performance of the acquiring firm or not. However, other studies on acquisition indicate that acquisitions have no financial benefits for the acquiring firms but rather customer expansion base (Amega, 2012). While target firm's shareholders generally enjoy positive short-term returns, investors in bidding firms may experience share price underperformance in the months following acquisition, with negligible or no overall wealth gains for portfolio holders in the company. Shareholders in the acquiring firms may also experience decreased earnings per share as a result of reduced profits. This work therefore aims to fill the existing research gap by determining the impact of Acquisitions on firms' financial performance.

\subsection{Research Questions}

i. What is the effect of acquisition Liquidity of Total Petroleum Ghana?

ii. What is the effect of acquisition on Profitability of Total Petroleum Ghana?

iii. What is the effect of acquisition on Asset Utilization of Total Petroleum Ghana? 


\subsection{Objective of the study}

The main objective of the study was to assess the impact of Acquisition on firms' financial performance.

The specific objectives were as follows

i. To assess Pre and Post-Acquisition liquidity of Total Petroleum Ghana.

ii. To determine the Pre and Post-Acquisition profitability of Total Petroleum Ghana.

iii. To evaluate Pre and Post-Acquisition asset utilization of Total Petroleum Ghana.

\subsection{Scope and Limitation of the study}

The study was based on the financial data obtained from Total Petroleum Ghana. Therefore, the quality of the study would largely depend on the accuracy, quality and reliability of the secondary data source.

Also, the data point was small so the sample does not highly stand for all acquired firms. The data available for pre-acquisition was only from 2002 to 2005 , due to that we could not get enough sample size.

The study only focused on internal factors but does not consider external factors such industry dooming and economic indication such as inflation, interest rate, GDP which had a great impact on profitability.

\section{Literature Review}

\subsection{Concept of Acquisition}

To cut it short, acquisitions simply refer to the coming together or takeover of two or more enterprises into a single entity. It refers to the coming together or takeover of two or more firms to become one big firm or pursuing similar motives. (Amedu et a, .2004). An activity is called acquisition when firms come together to combined and share their resources to achieve the same motive. In other acquisitions the owners of the new entity become joint owners (Sudarsanam, 1995).

However acquisition can also be describe as the situation whereby firm takes a controlling ownership interest in another firm, or an asset of another firm.

According to Soludo (2004), stated that acquisitions are aimed at achieving cost efficiency through economies of scale and to diversify and expand on the range of business activities for improved performance.

Also, Ernest and Young (1994) defined acquisition as the fusing of two or more companies whether voluntary or enforced. The efficiency theories says that a merger or acquisition can only happen when it is expected to generate enough realizable synergies to make the deal more important to all the parties involved. Therefore the expectations of gains which results in amicable acquisition being proposed and accepted.

\subsection{Theoretical Review}

Two different theories were therefore considered under efficiency theory and they are Differential efficiency theory and Synergy theory.

\subsection{Differential Efficiency Theory}

Based on differential efficiency theory if the management of company A is more efficient than the management of company $\mathrm{B}$ and if the company $\mathrm{A}$ acquires company $\mathrm{B}$, the efficiency of company $\mathrm{B}$ is most likely to be brought up to the level of the company A. The theory implies that companies that perform below their efficiency are more likely to be absorb by companies with higher efficiency rate. And when this happened the company with low efficiency rate will be lift up when acquired by the firm with higher efficiency rate. The only risk involve in this is when the high efficient company forecast higher outcome from the merger but at the end the resources only utilized lower outcomes.

\subsection{Synergy Theory}

Moreover, Synergy theory is the concept that assumed that the value of two firms when combined will be greater than two separate firms. (Brigham and Erhact, 2005). Synergies benefits are recognized if the value of the merged companies exceed the value of the companies separately. Financial benefit is mostly achieved through merging together of companies, is mostly the motive behind merger. Synergistic effect is realized when companies post acquisition share price increase in value. The expected outcome on acquisitions can be attributed to various factors, such as an increase in revenues, combined talent and technology or cost reduction can contributed to synergy. (Chang, 1990). Furthermore, market power is also a benefit that acquired firms enjoyed from operating synergy.

\section{Methodology of the Study}

The source of the data used in the research is secondary source of data published by Total Petroleum Company Limited on the Ghana Stock Exchange website.

Descriptive research design was therefore used in this study.

The target population for this study was the financial statement of Total Petroleum Company Limited and Mobil Oil Ghana. 
The sample size of the study is the financial statement of Total Petroleum Ghana Limited and Mobil Oil from 2002 to 2005 pre-acquisition and from 2007 to 2010 post-acquisition.

Techniques used in gathering data from the population were the purposive sampling technique.

The instrument use in the collection of the data was through the use of the computer internet.

The audited financial statement of Total Petroleum Ghana with the help of selected financial ratios and corresponding graphs computed using the data. The selected financial ratios were computed for the four years before and four years immediately after the acquisition. The calculation of the ratios and their corresponding graphs for periods surrounding the acquisition date helped in identifying and comparing the trends in corporate financial performance of the acquired company before and after the acquisition.

Performance indicator (class of ratio) were computed to measure the company's profitability.

\subsection{Research Variables}

3.1.1 Profitability Ratio A class of financial tools that are used to assess company's ability to generate earnings as compared to their expenses and other useful costs incurred during a particular time. Having higher value relative to a competitor's ratio or the same from a past period is a sign that the firm is doing good. Some examples of Profitability ratio examples are profit margin, return on equity, return on capital employed etc.

3.1.1.1 Net Profit Margin When calculating the Profit Margin is a ratio of profitability as calculated as the net income divided by revenues or the net profits divided by sales. It measures how much out of every Ghana cedi of sales a company actually keeps in earnings. Profit margin is very important when comparing companies in the same industries. A higher profit margin indicates a more profitable a company is as compare to its competitors.

3.1.1.2 Return on Equity This ratio is computed by net income over total equity.

3.1.1.3 Return on Capital Employed This ratio is computed by Operating Profit over Capital employed.

Net Profit Margin (NPM) $=\frac{\text { Net Profit Sales }}{\text { Turnover }} \times 100 \%$

Return on Equity $(\mathrm{ROE})=\frac{\text { Net Income }}{\text { Total Equity }} \times 100 \%$

Return on Capital Employed $=$ Operating Profits $=\frac{\text { Operating Profits }(P B I T)}{\text { Capital Employed }} \times 100 \%$

3.1.2 Assets Utilization Ratio Asset utilization ratio sometimes called efficiency ratio or activity ratio indicated how management utilizes and manages its assets in generating revenues by comparing sales to different types of assets. The intent is to obtain the speed at which assets generate revenue. Under this ratio assets turnover and fixed asset turnover were assessed.

3.1.2.1 Asset Turnover The total asset turnover ratio measures the ability of a company to use its assets to efficiently generate sales. This ratio considers all assets, noncurrent and current assets including plant and equipment, property, building, inventory, cash etc. The formula for measuring how efficiently a company is operating is calculated as

Assets Turnover $=\frac{\text { Sales } / \text { turnover }}{\text { Total Assets }} \times 100 \%$

3.1.2.2 Fixed Asset Turnover This is a measure of how effectively fixed assets are being used to generate sales. Fixed Assets Turnover $=\frac{\text { Sales } / \text { turnover }}{\text { Fixed assets }} \times 100 \%$

3.1.3 Liquidity Ratio The ability of a firm to carter for all its current obligations. Under this ratio current ratio and Acid Test Radio were assessed.

\section{Formula}

3.1.3.1 Current Ratio: Current Ratio $=\frac{\text { Current Asset }}{\text { Current Liability }}: 1$

3.1.3.2Quick Ratio or Acid Test: Acid Test $=\frac{\text { Current Assets-Inventory }}{\text { Current Liability }}: 11$

\subsection{Organizational Profile}

The background of the two companies have been compiled as follows;

\subsubsection{Total Petroleum Ghana LTD}

History and Background Mobil Oil Ghana Ltd (now TPGL) was incorporated on December 31, 1951 in accordance with the provisions of Companies Cap 193 of the Laws of Gold Coast under the name of Socony-Vacuum Oil Company (Gold Coast Limited), as a wholly owned subsidiary of Socony-Vacuum Oil Company, a company incorporated under the Laws of the State of New York in the United States of America. In 1955, the parent company, Socony-Vacuum Oil Company was renamed Socony Mobil Oil Company Inc, and renamed again in 1965 as Mobil Oil Corporation. The name of the Ghanaian subsidiary was thus changed to Mobil Oil Gold Coast Limited in 1955 and subsequently to Mobil Oil Ghana Limited in 1957 on attainment of independence by the Gold Coast. The shareholders of Mobil Oil Ghana Limited again approved a name change to Total Petroleum Ghana Ltd (TPGL) at an Annual General Meeting held on September 6, 2006. TPGL has therefore operated in Ghana 
for about fifty-three (53) years, during which time it became one of the major players in the oil marketing industry. TPGL enjoyed strong support and assistance from its parent company, Mobil Holdings UK. On

September 30, 2005 Mobil Holdings UK sold its stake in TPGL to Total Outre Mer, a subsidiary of Total S.A. Products TPGL's core operation is the marketing of petroleum products, automotive and other fuels, and specialties such as Liquefied Petroleum Gas (LPG), aviation fuel and lubricants, through both a retail network and other outlets. The following constitutes products and services offered by TPGL:

\subsubsection{Product / Service Features}

3.2.2.1 Aviation Aviation products includes aviation fuel (jet fuel) and aviation lubricating oil and greases for aircraft piston engines, aircraft gas turbines and general lubrication of aircraft parts. Black Products Refers to Residual Fuel Oil (RFO) sometime referred to as Fuel Oil is a heavy fuel generally used for firing of boilers. Bunkering an industrial term that refers to the supply of Fuel (Marine Diesel) and lubricating oil to vessels at the port or harbours Fuel Oil an industrial term that refers to the supply of Fuel (Marine Diesel) and lubricating oil to vessels at the port or harbours.

3.2.2.2 Lubricants A combination of base stock and additives: Base stocks are derived from crude oil that has been processed through a refinery. The primary function of a lubricant is to reduce friction between two moving parts. White Products This refers to light products such as Gasoline, Premium and Kerosene.

\subsubsection{Organizational Structure}

Total Ghana Ltd employs an effective organizational structure with clearly defined line of authority from top management downward. On the top of the hierarchy is the Board of Directors, (BOD) followed by the Managing Director (MD) and the Line Management. The line managements are the marketing manager, Logistic Manager, Internal Audit, Legal Officer, Network Manager, Human Resource Manager, Finance and Accounting and the Area Manager.

3.2.4 The SWOT Analysis: According to Kotler, 1999 a SWOT analysis is the summary of the strengths and weaknesses of the company together with the opportunities and threats it faces.

i. Strength • Their customers are the big Mining companies in the country and the construction industries. • They have about two hundred and twenty - five retail outlets in the country. $\bullet$ Large customers and goodwill

ii. Weakness There is high labour turnover and competition from other companies.

iii. Opportunities $\bullet$ Political stability. $\bullet$ Macro - Economic stability.

iv. Threat $\bullet$ New entrants and competition of other petroleum companies in the industry.

\section{Data Analysis and Interpretation of Results}

There was analyses of data to compare the performance of TOTAL Ghana four years before the acquisition of Mobil (2002-2005), and four years after (2007-2010). Three performance measures were looked at- Liquidity, Profitability, and Asset Utilization. The performance comparison was done in two stages for each of the financial measures analyzed- comparison of the pre and post-acquisition period averages, and then an assessment of the statistical significance in differences (if any) observed.

4.1.1 Liquidity Two liquidity ratios were assessed- the Current Ratio and the Quick Ratio. The current ratio is a liquidity and efficiency ratio that measures a firm's ability to pay off its short-term liabilities with its current assets. The quick ratio or acid test ratio on the other hand is a liquidity ratio that measures the ability of a company to pay its current liabilities when they come due with only quick assets. Quick assets are current assets that can be converted to cash within 90 days or in the short-term.

4.1.1.1 Numerical Comparison

Table 1. Descriptive Statistics for Liquidity Comparison

\begin{tabular}{|l|l|l|l|l|l|}
\hline Group Statistics & & & & \\
\hline & Period & $\mathrm{N}$ & Mean & Std. Deviation & $\begin{array}{l}\text { Std. Error } \\
\text { Mean }\end{array}$ \\
\hline \multirow{2}{*}{ Current Ratio } & Pre-Acquisition & 4 & .858801 & .0876769 & .0438385 \\
\cline { 2 - 7 } & Post-Acquisition & 4 & 1.028381 & .0354663 & .0177331 \\
\hline \multirow{2}{*}{ Quick Ratio } & Pre-Acquisition & 4 & .679265 & .0593055 & .0296527 \\
\cline { 2 - 7 } & Post-Acquisition & 4 & .822787 & .0816347 & .0408174 \\
\hline
\end{tabular}

Source SPSS Data Analysis (2020)

Current ratio for the pre-acquisition period was $0.8588(0.86 \%)$; and $1.0283(102 \%)$ for the post-acquisition period; with standard deviations of 0.0876 and 0.0354 respectively. This means that the post-acquisition current ratio was higher and more stable than the pre-acquisition current ratio.

Quick Ratio for the pre-acquisition period was $0.6792(67.9 \%)$; and $0.8227(82.2 \%)$ for the post-acquisition period; with standard deviations of 0.0593 and 0.0816 respectively. This means that the post-acquisition quick ratio was higher but less stable compared to the pre-acquisition quick ratio. These comparisons are illustrated in figure 1 below. 


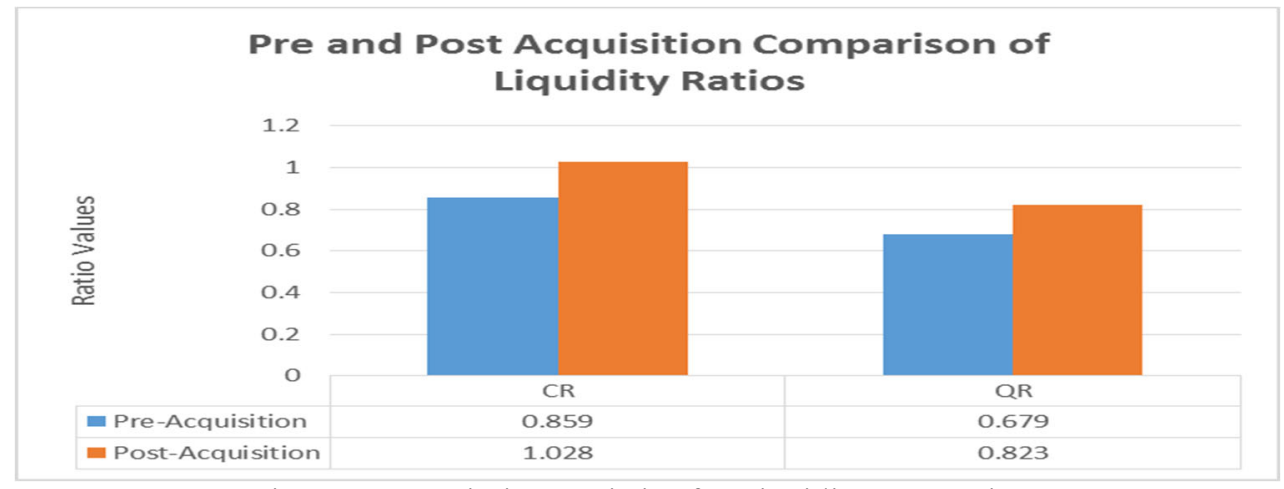

Figure 1. Descriptive Statistics for Liquidity Comparison

Figure 1 clearly shows which periods had higher performance for the liquidity ratios. Post-acquisition current and quick ratios were higher than the pre-acquisition ratios. The next section shows whether the differences were statistically significant.

\subsubsection{Statistical Comparison}

Table 2 below shows the independent samples test in SPSS. There are two rows of results for each liquidity measure. The results also include the Levene's Test for equality of variances to help us determine which row to accept as our result for interpretation. For an independent samples test to be comparable ideally, there must be little variance in the two groups. The Levene's test therefore shows which result has the lowest variance; which we then accept for interpretations. If the sig value for equal variances is less than $5 \%$, it means that the variance is large and significant, we therefore take the second row's results; otherwise we take the equal variance results. Table 2. Statistical Comparison for differences in Profitability Ratios

\begin{tabular}{|c|c|c|c|c|c|c|c|c|}
\hline \multicolumn{9}{|c|}{ Independent Samples Test } \\
\hline & \multirow{2}{*}{$\begin{array}{l}\text { Levene's Test for } \\
\text { Equality of } \\
\text { Variances }\end{array}$} & \multicolumn{7}{|c|}{ t-test for Equality of Means } \\
\hline & & $\mathrm{F}$ & Sig & $\mathrm{t}$ & Df & $\begin{array}{l}\text { Sig. (2 } \\
\text { tailed) }\end{array}$ & Mean Difference & $\begin{array}{l}\text { Std. Error } \\
\text { Difference }\end{array}$ \\
\hline \multirow[t]{2}{*}{$\begin{array}{l}\text { Current } \\
\text { Ratio }\end{array}$} & $\begin{array}{l}\text { Equal variances } \\
\text { assumed }\end{array}$ & 1.671 & .244 & -3.586 & 6 & .012 & -.1695798 & .0472893 \\
\hline & $\begin{array}{l}\text { Equal variances } \\
\text { not assumed }\end{array}$ & & & -3.586 & 3.956 & .023 & -.1695798 & .0472893 \\
\hline \multirow{3}{*}{$\begin{array}{l}\text { Quick } \\
\text { Ratio } \\
\end{array}$} & $\begin{array}{l}\text { Equal variances } \\
\text { assumed }\end{array}$ & .131 & .730 & -2.845 & 6 & .029 & -.1435222 & .0504514 \\
\hline & Equal & & & -2.845 & 5.477 & .033 & -.1435222 & .0504514 \\
\hline & $\begin{array}{l}\text { variances } \\
\text { not assumed }\end{array}$ & & & & & & & \\
\hline
\end{tabular}

Source SPSS Data Analysis (2020)

The results from the table however indicate that there were equal variances for both measures (sig value greater than 5\%). This means that the first row results are ideal for our analysis. The results show that postacquisition CR was higher by $16.9 \%$ and this difference is significant (p-value or sig value of 0.012 ; less than 5). Post-acquisition QR was higher by $14.3 \%$ and this difference is significant (p-value or sig value of 0.029 ; less than $5 \%$ ).

4.1.2.1 Profitability Three profitability ratios were assessed- the Net Profit Margin, Return on Equity, and Return on Capital Employed.

4.1.2.1 Numerical Comparison This section compares the absolute figures from the pre and post-acquisition periods. Table 3 below shows the descriptive statistics for the profitability comparison.

Table 3. Descriptive Statistics for Profitability Comparison

\begin{tabular}{|l|l|l|l|l|l|}
\hline Group Statistics & Pre or Post Acquisition & $\mathrm{N}$ & Mean & Std. Deviation & $\begin{array}{l}\text { Std. Error } \\
\text { Mean }\end{array}$ \\
\hline \multirow{2}{*}{ Net Profit Margin } & Pre-Acquisition & 4 & .009290 & .0147559 & .0073780 \\
\cline { 2 - 6 } & Post-Acquisition & 4 & .020982 & .0074777 & .0037389 \\
\hline \multirow{2}{*}{ Return on Equity } & Pre-Acquisition & 4 & .134491 & .2262466 & .1131233 \\
\cline { 2 - 6 } & Post-Acquisition & 4 & .198344 & .0914400 & .0457200 \\
\hline \multirow{2}{*}{$\begin{array}{l}\text { Return on Capital } \\
\text { Employed }\end{array}$} & Pre-Acquisition & 4 & .335784 & .1035121 & .0517561 \\
\cline { 2 - 6 } & Post-Acquisition & 4 & .280635 & .0851138 & .0425569 \\
\hline
\end{tabular}

Source: SPSS Data Analysis (2020) 
Average Net Profit Margin for the pre-acquisition period was $0.0093(0.9 \%)$; and $0.022(2 \%)$ for the postacquisition period; with standard deviations of 0.015 and 0.007 respectively. This means that the post-acquisition NPM was higher and more stable than the pre-acquisition NPM. Average Return on Equity for the pre-acquisition period was $0.134(13.4 \%)$; and $0.198(19.8 \%)$ for the post-acquisition period; with standard deviations of 0.226 and 0.091 respectively. This means that the post-acquisition ROE was higher and more stable than the preacquisition ROE.

Average Return on Capital Employed for the pre-acquisition period was 0.336 (33.6\%); and $0.281(28.1 \%)$ for the post-acquisition period; with standard deviations of 0.103 and 0.085 respectively. This means that the preacquisition ROCE was higher but less stable than the post-acquisition ROCE. These comparisons are illustrated in figure 2 below.

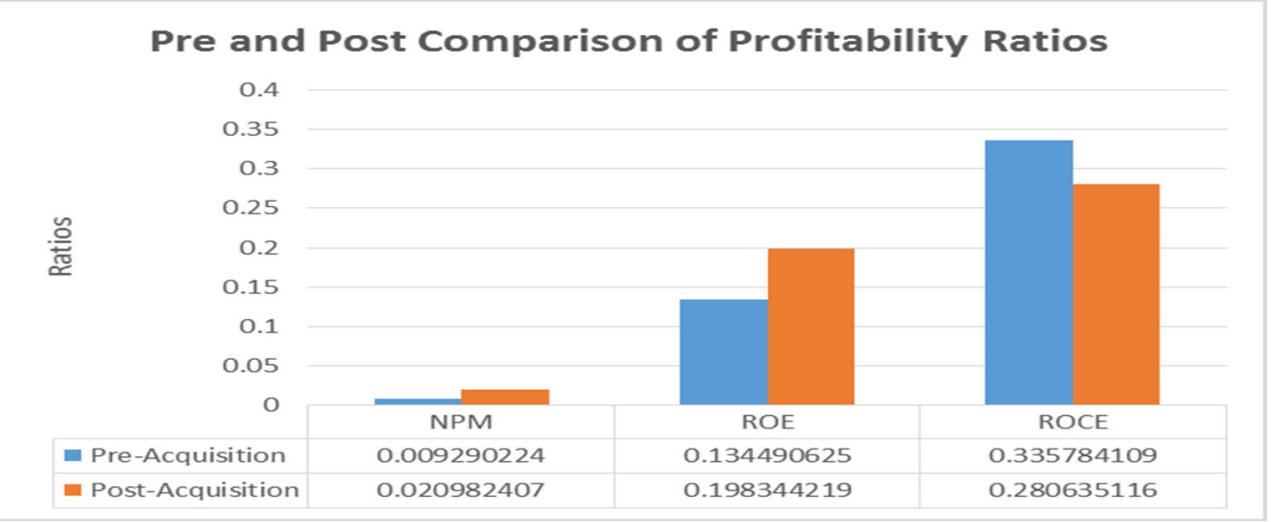

Figure 2. Comparison of Profitability Ratios

Figure 2 clearly shows which periods had higher performance for the profitability ratios. Post-acquisition NPM and ROE were higher, and pre-acquisition ROCE was higher. The next section shows whether the differences were statistically significant.

\subsubsection{Statistical Comparison}

Table 4 below shows the independent samples test in SPSS. There are two rows of results for each profitability measure. The results also include the Levene's Test for equality of variances to help us determine which row to accept as our result for interpretation. For an independent samples test to be comparable ideally, there must be little variance in the two groups. The Levene's test therefore shows which result has the lowest variance; which we then accept for interpretations. If the sig value for equal variances is less than $5 \%$, it means that the variance is large and significant, we therefore take the second row's results; otherwise we take the equal variance results.

Table 4. Statistical Comparison for differences in Profitability Ratios.

\begin{tabular}{|c|c|c|c|c|c|c|c|c|}
\hline \multicolumn{9}{|c|}{ Independent Samples Test } \\
\hline & & \multicolumn{2}{|c|}{$\begin{array}{l}\text { Levene's Test } \\
\text { for Equality of } \\
\text { Variances }\end{array}$} & \multicolumn{5}{|c|}{ t-test for Equality of Means } \\
\hline & & $\mathrm{f}$ & sig & $\mathrm{t}$ & $\mathrm{Df}$ & $\begin{array}{l}\text { Sig. } \\
(2 \\
\text { tailed })\end{array}$ & $\begin{array}{l}\text { Mean } \\
\text { Difference }\end{array}$ & $\begin{array}{l}\text { Std. Error } \\
\text { Difference }\end{array}$ \\
\hline \multirow{2}{*}{$\begin{array}{l}\text { Total Asset } \\
\text { Turnover } \\
\text { Ratio }\end{array}$} & $\begin{array}{l}\text { Equal variance } \\
\text { assumed }\end{array}$ & 1.346 & .290 & -1.414 & 6 & .207 & -.0116922 & .0082712 \\
\hline & $\begin{array}{l}\text { Equal Variance } \\
\text { not assumed }\end{array}$ & & & -1.414 & 4.446 & .224 & -.0116922 & .0082712 \\
\hline \multirow[t]{2}{*}{ Fixed Assets } & $\begin{array}{l}\text { Equal variance } \\
\text { assumed }\end{array}$ & 2.462 & .168 & -.523 & 6 & .619 & -.0638536 & .1220131 \\
\hline & $\begin{array}{l}\text { Equal variance } \\
\text { not assumed }\end{array}$ & & & -.523 & 3.955 & .629 & -.0638536 & .1220131 \\
\hline \multirow{2}{*}{$\begin{array}{l}\text { Return on } \\
\text { capital } \\
\text { employed }\end{array}$} & $\begin{array}{l}\text { Equal variance } \\
\text { assumed }\end{array}$ & .806 & .404 & .823 & 6 & .442 & .0551490 & .0670058 \\
\hline & $\begin{array}{l}\text { Equal variance } \\
\text { not assumed }\end{array}$ & & & .823 & 5.784 & .443 & .0551490 & .0670058 \\
\hline
\end{tabular}

Source SPSS Data Analysis (2020)

The results from the table however indicate that there were equal variances for all three measures (sig value greater than 5\%). This means that the first row results are ideal for our analysis. The results show that postacquisition NPM was higher by $1.1 \%$ but this difference is insignificant (p-value or sig value of 0.207 ; greater 
than 5). Post-acquisition ROE was higher by $6.4 \%$ but this difference is insignificant (p-value or sig value of 0.619 ; greater than 5\%). Post-acquisition ROCE was lower by $5.5 \%$ but this difference is insignificant (p-value or sig value of 0.442 ; greater than $5 \%$ ). This means that there was no significant difference in profitability performance within the first four years of the acquisition.

\subsubsection{Asset Utilization}

The asset utilization ratio measures the total revenue earned for every Cedi of assets the company owns. Two ratios were assessed- the Fixed Assets Turnover, and the Total Assets Turnover.

\subsubsection{Numerical Comparison}

This section compares the absolute figures from the pre and post-acquisition periods. Table 4.5 below shows the descriptive statistics for the asset utilization comparison.

Table 5. Descriptive Statistics for Asset Utilization Comparison

\begin{tabular}{|l|l|l|l|l|l|}
\hline Group Statistics & Period & $\mathrm{N}$ & Mean & Std. Deviation & Std. Error Mean \\
\hline \multirow{2}{*}{$\begin{array}{l}\text { Total Assets } \\
\text { Turnover Ratio }\end{array}$} & Pre-Acquisition & 4 & 4.230509 & .5042966 & .2521483 \\
\cline { 2 - 6 } & Post-Acquisition & 4 & 3.839493 & .6318405 & .3159203 \\
\hline $\begin{array}{l}\text { Fixed Assets } \\
\text { Turnover }\end{array}$ & Pre-Acquisition & 4 & 11.838151 & 1.9510491 & .9755246 \\
\cline { 2 - 6 } & Post-Acquisition & 4 & 9.498861 & 1.8108785 & .9054393 \\
\hline
\end{tabular}

Source SPSS Data Analysis (2020).

Average Total Assets Turnover Ratio for the pre-acquisition period was 4.23; and 3.84 for the post-acquisition period; with standard deviations of 0.504 and 0.631 respectively. This means that the post-acquisition TATR was lower and less stable than the pre-acquisition TATR. In absolute terms, Asset Utilization was better in the preacquisition period. For every GHф1 in assets, the company generated GHф4.23 in the pre-acquisition period; and GHф3.84 in the post-acquisition period. Average Fixed Assets Turnover Ratio for the pre-acquisition period was 11.8; and 9.5 for the post-acquisition period; with standard deviations of 1.95 and 1.81 respectively. This means that the post-acquisition FATR was lower and less stable than the pre-acquisition FATR. In absolute terms, FATR was better in the pre-acquisition period. For every GHф1 in fixed assets, the company generated GH $\notin 11.8$ in the pre-acquisition period; and GH $\notin 9.5$ in the post-acquisition period.

This is illustrated in figure 3 below.

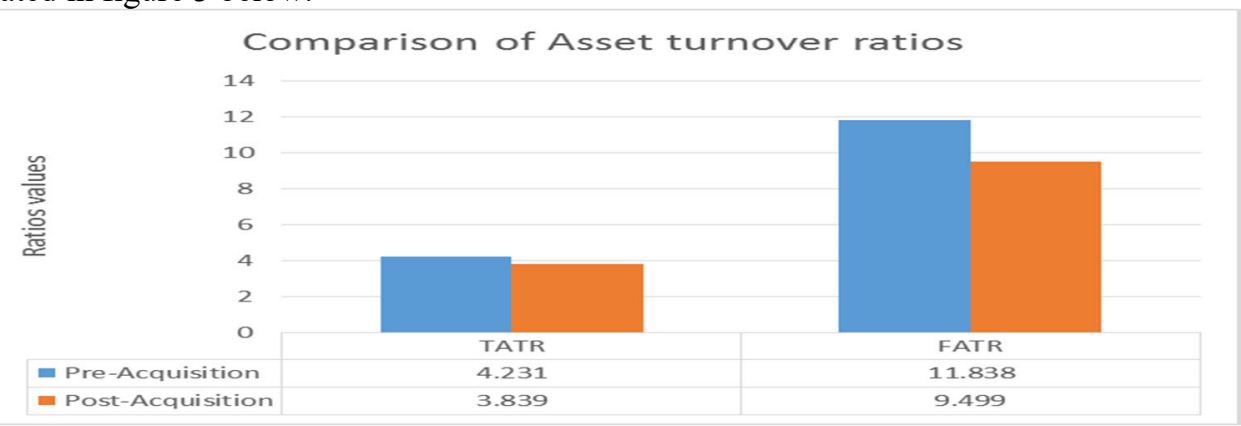

Figure 3. Comparison of Asset Turnover Ratios

Figure 3 show clearly that asset turnover was higher in the pre-acquisition period.

The next section determines whether the difference is statistically significant.

\subsubsection{Statistical Comparison:}

Table 6 below shows the statistical results.

Table 6 Statistical Comparison for differences in Asset Turnover Ratio

\begin{tabular}{|l|l|l|l|l|l|l|l|l|}
\hline \multicolumn{2}{|l|}{ Independent Samples Test } \\
\hline \multicolumn{2}{|l|}{$\begin{array}{l}\text { Levene's Test } \\
\text { for Equality of } \\
\text { Variances }\end{array}$} \\
\cline { 2 - 10 } \\
\cline { 2 - 10 }
\end{tabular}


The Levene's test shows that the first row results are ideal (sig value greater than 5\%), which means there is no significant difference in variances between the two groups. The first row results show that indeed the preacquisition TATR was 0.39 higher than the post-acquisition period but this difference is statistically insignificant (p-value of 0.371; greater than 5\%); and the pre-acquisition FATR was 2.3 higher than the post-acquisition period but this difference is statistically insignificant.

\subsection{Key Findings}

\subsubsection{To asses Pre and Post-Acquisition liquidity of total petroleum Ghana}

Current ratio for the pre-acquisition period was $0.8588(0.86 \%)$; and $1.0283(102 \%)$ for the post-acquisition period; with standard deviations of 0.0876 and 0.0354 respectively. This means that the post-acquisition current ratio was higher and more stable than the pre-acquisition current ratio. Quick Ratio for the pre-acquisition period was 0.6792 $(67.9 \%)$; and $0.8227(82.2 \%)$ for the post-acquisition period; with standard deviations of 0.0593 and 0.0816 respectively. This means that the post-acquisition quick ratio was higher but less stable compared to the preacquisition quick ratio. Per the findings it shows evidence of the work of Healey 1992 who concluded that postacquisition assets efficiency increase and as a results increase cash flow to meet daily obligations.

\subsubsection{To determine the Pre and post-Acquisition profitability of total petroleum Ghana}

Average Net Profit Margin for the pre-acquisition period was $0.0093(0.9 \%)$; and $0.022(2 \%)$ for the postacquisition period; with standard deviations of 0.015 and 0.007 respectively. This means that the post-acquisition NPM was higher and more stable than the pre-acquisition NPM.

Average Return on Equity for the pre-acquisition period was 0.134 (13.4\%); and $0.198(19.8 \%)$ for the postacquisition period; with standard deviations of 0.226 and 0.091 respectively. This means that the post-acquisition ROE was higher and more stable than the pre-acquisition ROE. Average Return on Capital Employed for the preacquisition period was $0.336(33.6 \%)$; and $0.281(28.1 \%)$ for the post-acquisition period; with standard deviations of 0.103 and 0.085 respectively. This means that the pre-acquisition ROCE was higher but less stable than the post. This findings are evidenced by the findings of Diaz, Olalla and Azofra (2004) who examined the bank performance derived from both the acquisition of another bank and acquisition of nonbanking financial entities in the European Union. The sample consisted of 1,629 banks, where 181 acquisitions were noted over the period 1993-2000. They found some evidence on the impact of takeover on the acquirer when acquiring non-bank firms and when the sample was split by type of acquirer (i.e. commercial banks, savings banks, cooperative banks). In particular their results revealed that the acquisition of financial entities by European banks can increase their profitability. However, a lag of at least two years between the acquisition.

\subsubsection{To evaluate Pre and Post-Acquisition asset utilization of total petroleum Ghana}

Average Total Assets Turnover Ratio for the pre-acquisition period was 4.23; and 3.84 for the post-acquisition period; with standard deviations of 0.504 and 0.631 respectively. This means that the post-acquisition TATR was lower and less stable than the pre-acquisition TATR. In absolute terms, Asset Utilization was better in the preacquisition period. For every GH $\propto 1$ in assets, the company generated GH $\phi 4.23$ in the pre-acquisition period; and $\mathrm{GH} \notin 3.84$ in the post-acquisition period. Average Fixed Assets Turnover Ratio for the pre-acquisition period was 11.8; and 9.5 for the post-acquisition period; with standard deviations of 1.95 and 1.81 respectively. This means that the post-acquisition FATR was lower and less stable than the pre-acquisition FATR. In absolute terms, FATR was better in the pre-acquisition period. For every GHф1 in fixed assets, the company generated GH $\notin 11.8$ in the pre-acquisition period; and GH $\notin 9.5$ in the post-acquisition period. This results strongly disagrees with Ruback et al, 1992 who concluded that acquisition improves Asset productivity of firms which contributes to higher operating cash flow returns relative to their rates of capital expenditure and R\&D relative to their industries, suggesting that the improved performance is not at the expense of fundamental investment in the business.

\section{Summary of Findings and Conclusions}

The study sought to assess the performance of TOTAL Petroleum four years before and after the acquisition of Mobil Oil in 2006. Performance was assessed in investment, profitability, and asset utilization.

\subsection{Summary of Findings}

Current Ratio and Quick Ratio were higher in the post-acquisition period compared to the pre-acquisition period; and the differences were significant. Net Profit Margin and Return on Equity were higher in the post-acquisition period, while ROCE was lower. The differences were all statistically insignificant. Asset Turnover was lower in the post-acquisition period, but the difference was insignificant.

\subsection{Conclusions}

In terms of liquidity, there was a significant impact of the acquisition on the performance. Post-acquisition liquidity ratios indicated significantly higher performance. However, for the profitability and assets utilization, the preacquisition performances were better than the first four years of the post-acquisition period, although these 
differences were statistically insignificant.

\subsection{Recommendations}

Further studies should extend the period of the research. Any researcher who wants to search on same or similar topic should use both primary and secondary data. They should also focus on external environment and also use more sample size to generalize the conclusion.

\section{References}

Amedu S (2004). Corporate Takeover, Acquisition and Merger. The Nigerian Stockbroker, the Official J. Chartered Inst. Stockbrokers, January - March.

Amegah, W. (2012). 'Merger and Acquisition', Thesis, Page 15.

Anderson, Helen, Virpi, H. and Asta, S. (2001). 'Can You Buy a Business Relationship? On The Importance of Customer and Supplier Relationships in Acquisitions', Industrial Marketing Management, 30, pp. 575-586.

Brigham and Ehrahardt (2005), 'Financial Management Theory and Practice', 11th edition Paperback - 1601

Brigham, F. E. (2005), 'Fundamentals of Financial Management' (Chicago, The Dryden Press)

CHANG, C.W. and CHANG, S. K. (1990), 'The Journal of Finance', Volume 45, Issue 4, September 1990, Pages $1333-1336$.

Diaz, B.D., Olalla, M.G. and light, S.S. (2004), 'Bank Acquisitions and Performance: Evidence from a Panel of European Credit Entities', Journal of Economics and Business, 56, 377-404.

Ernest and Young, LLP. (1994),' Mergers and Acquisition', 2nd Edition, 364 pages

Ginsburg, Martin D. and Jack S. Levin, (1989), 'Mergers, Acquisitions and Leveraged Buyouts',

Healy, P. M, Palepu, K. G and Ruback. R. S. (1992) 'Does corporate performance improve after the mergers?' Journal of financial economics 31, 135-175.

http://www.encyclopedia.com/social-sciences-and-law/economics-business-and-labor/money banking-andinvestment/acquisitions-and (accessed: 07/10/16).

http://www.investopedia.com/university/mergers/mergers1.asp

Kotler P., Dubois B. (1992), "Marketing management", Edition 7,

Soludo (2004) Journal of Finance and Investment Analysis, vol. 2, no.4, 2013, 185-195 ISSN:

Sudarsanam, (1995). "The Essence of Mergers and Acquisitions", illustrated Edition, page 201

Pre-Acquisition:

\section{Ratios:}

\begin{tabular}{|lcccc|}
\hline Column1 & Column2 & Column3 & Column4 & Column5 \\
\hline Profitability & 2002 & 2003 & 2004 & 2005 \\
\hline Net Profit Margin & 0.0175978 & 0.02046169 & -0.012061 & 0.0111627 \\
\hline Return on Equity & 0.19942197 & 0.28010907 & -0.200976 & 0.2594071 \\
\hline Return on Capital Employed & 0.28633163 & 0.4264432 & 0.2136164 & 0.4167452
\end{tabular}

\section{Asset utilisation}

\begin{tabular}{|lrrrr|}
\hline Asset Ratio Turnover & 4.20401477 & 4.41305887 & 3.5538401 & 4.7511219 \\
\hline Fixed Asset Turnover & 13.6407035 & 11.491575 & 9.2405995 & 12.979726 \\
\hline Liquidity & & & & \\
\hline Current Ratio & 0.98304643 & 0.8580323 & 0.7977276 & 0.7963971 \\
\hline Quick Ratio & 0.74300122 & 0.644865 & 0.6152239 & 0.7139707 \\
\hline
\end{tabular}

Post-Acquisition:

\begin{tabular}{lccrr|}
\hline Column1 & Column2 & Column3 & Column4 & Column5 \\
Profitability & 2007 & 2008 & 2009 & 2010 \\
\hline Net Profit margin & 0.02019585 & 0.010979 & 0.0242719 & 0.02848249 \\
Return on Equity & 0.14454611 & 0.111909 & 0.2190354 & 0.3178866 \\
\hline Return on Capital employed & 0.24295825 & 0.199064 & 0.2830338 & 0.39748487
\end{tabular}




\begin{tabular}{|lrrrr|}
\hline Asset Utilisation & & & & \\
\hline Asset Turnover Ratio & 3.07226536 & 3.971621 & 3.7155138 & 4.59857172 \\
\hline Fixed Asset Turnover & 7.15108003 & 9.995571 & 9.3367816 & 11.512012 \\
\hline & & & & \\
\hline Liquidity & & & & \\
\hline Current Ratio & 0.99874788 & 1.040175 & 1.0733366 & 1.00126355 \\
\hline Quick Ratio & 0.86097813 & 0.830619 & 0.893087 & 0.70646549 \\
\hline
\end{tabular}

Financial Statement Used for the work:

Pre-Acquisition:

FINANCIAL STATEMENTS USED FOR THE WORK PRE ACQUISITON

Sales/Turnover

Cost of Sales

Gross Profit

Selling and Distribution Expenses

Restructuring Costs

Operating Profit/ Loss

Other Income

Profit Before Finance Charges and Exceptional Items

Finance Charges /Interest (net)

Profit Before Exceptional Items

Exceptional Items

Profit/(Loss) Before Tax \& NRL

NRL

Taxation

Profit After Tax

Dividend Proposed

Earnings per share (GHc per share)

Dividend per share (Ghc per share)

Closing Share Price

Non-Current Assets

Plant, Property \& Equipment

Intangible Assets

Long term Investments

Long term leases

Investments in subsidiary

\section{Current Assets}

Stock

Income Tax Asset

Accounts receivable

Amounts due from group companies

Deposit for shares

Cash \& bank balances

\section{Total Assets}

\section{Current Liabilities}

Bank overdrafts

Accounts Payable

Amounts due to group companies

Tax

Dividend Payable
2002

70,577

62,450

$\mathbf{8 , 1 2 7}$

7,599

528

1,261

1,789

105

1,684

1,684

42

400

1,242

1,032

\section{3}

90,364

79,871

$\mathbf{1 0 , 4 9 3}$

8,910

$\mathbf{1 , 5 8 3}$

1,394

2,977

141

2,836

$-$

71

916

$\mathbf{1 , 8 4 9}$

1,478

$\begin{array}{cc}6,352 & 8,857 \\ 36 & 372 \\ 55 & 55\end{array}$

6,443

9,284

2,761

261

6,602

489

3,458

$$
437
$$

7,450

1,194

11,307

17,750

901

13,919

23,203

5

8,827

9,308

280

55

55

9,199

$\mathbf{9 , 6 4 3}$

3,582

796

9,388

1,101

1,757

838

13,000

784

597

16,976

26,619

$\begin{array}{rrrr}809 & 2,084 & 1,514 & 3,099 \\ 6,099 & 8,522 & 13,078 & 16,986 \\ 3,557 & 4,138 & 4,035 & - \\ 4 & - & - & - \\ 1,033 & 1,478 & 1,000 & 1,231 \\ \mathbf{1 1 , 5 0 2} & \mathbf{1 6 , 2 2 2} & \mathbf{1 9 , 6 2 7} & \mathbf{2 1 , 3 1 6}\end{array}$


Non-current Liabilitie

Long-term Provisions

Deferred Taxation

Corporate Term loan

$\begin{array}{rr}(22) & (380) \\ & \\ (\mathbf{2 2}) & (380) \\ \mathbf{1 9 5 )} & (\mathbf{2 , 3 0 3}) \\ \mathbf{1 , 4 8 0} & \mathbf{1 5 , 8 4} \\ \mathbf{6 , 2 2 9} & \mathbf{6 , 6 0} \\ 33 & 3 \\ 6 & \\ 6,189 & 6,56 \\ \mathbf{6 , 2 2 8} & \mathbf{6 , 6 0} \\ \mathbf{1 , 5 3 8} & \mathbf{1 , 6 3}\end{array}$

(102)

(41)

Net Current Assets / (Liabilities)

(380)

(102)

Total Liabilities

Net Assets

Stated Capital

Capital Surplus Account

Income Surplus Account

Shareholders Fund

Net Assets Per Share (GHc)

1,538

1,630

$(3,970)$

19,525

$\mathbf{5 , 1 2 5}$

39

33

5,562

5,080

$\mathbf{5 , 1 2 5}$

1,085

(4,340)

21,275

5,262

\section{POST ACQUISITION}

Sales/Turnover

Cost of Sales

2009

566,514

374,236

534,101

542,439

2010

30,154

Gross Profit

32,413

502,393

738,910

22,953

Restructuring Costs

Operating Profit/ Loss

27,436

40,046

685,737

$\mathbf{5 3 , 1 7 3}$

$32,756 \quad 33,058$

7,201

6,324

Other Income

$\mathbf{4 , 9 7 7}$

7,290

7,182

10,947

12,159

18,237

$\mathbf{2 0 , 1 1 5}$

13,525

Finance Charges /Interest (net)

Profit Before Exceptional Items

4,065

2,080

7,668

10,643

$\mathbf{8 , 0 9 4}$

16,157

Exceptional Items

Profit/(Loss) Before Tax \& NRL

NRL

Taxation

Profit After Tax

Dividend Proposed

Earning per share (GHc per share)

Dividend per share (Ghc per share)

Closing Share Price

Non-Current Assets

Plant, Property \& Equipment

Intangible Assets

Long term Investments

Long term leases

Investments in subsidiary

\section{Current Assets}

Stock

Income Tax Asset

Accounts receivable

Amounts due from group companies

Deposit for shares

Cash \& bank balances

10,643

8,094

16,157

27,176

2,476

$\mathbf{8 , 1 6 7}$

1,874

2,991

13,166

21,046

0.5840

6,220

0.9415

.5050

0.4964

5.491

0.4448

0.9415

1.5050

7.600

6.800

2.200

42,488

41,588

45,859

57,287

13,225

15,981

12,738

12,460

57

14

14

14

55,770

11,223

753

57,701

53

57,583

58,611

69,761

11,630

81,360

18,246

14,312

31,730

734

1,201

1,281

58,615

58,925

67,798

137,130

12,927

10,786

6,960

Total Assets

148,151

107,769

Current Liabilities

Bank overdrafts

Accounts Payable

Amounts due to group companies

Tax

Dividend Payable

$\begin{array}{rrrr}20,950 & 31,519 & 4,380 & 897 \\ 50,054 & 48,516 & 72,168 & 91,768 \\ 7,224 & 7,035 & 2,853 & 14,968 \\ - & - & - & \\ 3,234 & & & \\ \mathbf{8 1 , 4 6 2} & \mathbf{8 7 , 0 7 0} & \mathbf{7 9 , 4 0 1} & \mathbf{1 0 7 , 6 3 3}\end{array}$


Non-current Liabilitie

Long-term Provisions

Deferred Taxation

Corporate Term loan

Net Current Assets / (Liabilities)

Total Liabilities

Net Assets

Stated Capital

Capital Surplus Account

Income Surplus Account

Shareholders Fund

$\begin{array}{rrrr}833 & 5,500 & 4,025 & 3,691 \\ \mathbf{8 3 3} & \mathbf{5 , 5 0 0} & \mathbf{4 , 0 2 5} & \mathbf{3 , 6 9 1} \\ \mathbf{( 1 0 2 )} & \mathbf{3 , 4 9 8} & \mathbf{5 , 8 2 3} & \mathbf{1 3 6} \\ \mathbf{8 2 , 2 9 5} & \mathbf{9 2 , 5 7 0} & \mathbf{8 3 , 4 2 6} & \mathbf{1 1 1 , 3 2 4} \\ \mathbf{5 5 , 6 6 8} & \mathbf{6 1 , 0 8 1} & \mathbf{6 4 , 4 3 4} & \mathbf{6 9 , 8 9 7} \\ 50,052 & 49,722 & 49,722 & 49,722 \\ 7 & & & \\ 6,442 & 5,859 & 10,387 & 16,484 \\ \mathbf{5 6 , 5 0 1} & \mathbf{5 5 , 5 8 1} & \mathbf{6 0 , 1 0 9} & \mathbf{6 6 , 2 0 6}\end{array}$

Net Assets Per Share (GHc)

4.0403 